\title{
Apoptosis Comparison Effects Between Synthetic and Natural B -Carotene from Dunaliella salina on MDA-MB-231Brest Cancer Cells
}

Jorge Olmos ${ }^{1 *}$, Rocío Gómez ${ }^{1}$ and Viviana P. Rubio ${ }^{2}$

${ }^{1}$ Molecular Microbiology Laboratory, Department of Marine Biotechnology, Centro de Investigación Científica y de Educación Superior de Ensenada (CICESE), Ensenada, B.C., México

${ }^{2}$ Marine Science Faculty, Universidad Autónoma de Baja California (UABC), Ensenada, B.C., México

\begin{abstract}
Dunaliella salina is genus most important species for $\beta$-carotene production. Several investigations have demonstrated that $D$. salina produces more than $10 \%$ of its dry mass. $\beta$-carotene is an important pro-vitamin $A$ source and can also act as a lipid radical scavenger and as a singlet oxygen quencher. Vitamin A Deficiency (VAD) has been related with cancer, for this reason synthetic and natural $\beta$-carotene has been used for prevention and treatment of the disease. Synthetic $\beta$-carotene is cheaper than natural molecule but only contains all-trans- $\beta$-carotene (AT $\beta C$ ), while 9-cis- $\beta$-carotene $(9 C \beta C$ ) and AT $\beta C$ are both produce by $D$. salina. Meta-analysis of controlled trials using high levels of synthetic $\beta$-carotene supplementation in smoker's individuals, mention that instead to prevent and control lung cancer, treatment increases risk and percentage of positive cases. Results obtained in cancer cell lines and animal models using $\beta$-carotene from Dunaliella, prevented and controlled diseases proliferation. In this work, effects of synthetic and natural $\beta$-carotene from $D$. salina were evaluated on MDA-MB-231 breast cancer cells, and even when apoptosis induction results were obtained with both sources, natural $\beta$-carotene generates considerable higher cell rates mortality.
\end{abstract}

Keywords: D. salina; $\beta$-carotene; AT $\beta$ A; $9 \mathrm{C} \beta \mathrm{A} ; \mathrm{MDA}-\mathrm{MB}-231$

\section{Introduction}

Breast cancer is most frequently diagnosed cancer globally and main cause of death among women $[1,2]$. Breast cancer is a complex disorder that can occur because of vitamin deficiencies and due process including oxidative stress and lipid peroxidation. Biological mechanisms exist to support anticancer properties of natural antioxidant pro-vitamin A molecule ( $\beta$-carotene) in animals and overall impression is that intake of it, play a substantial role in prevention of cancer [3-5]. However, anticancer effects are not so positive in humans using synthetic $\beta$-carotene molecule [6-8].

Dunaliella genus includes a reduced number of species that when exposed to elevated luminous intensities, high saline concentrations and limited conditions of oxygen and nitrogen accumulate great amounts of $\beta$-carotene $[9,10]$. D. salina and $D$. bardawil are the most important species of the genus for $\beta$-carotene production. Several investigations have demonstrated that both species produces more than $10 \%$ of its dry mass $[11,12]$. The commercial production of $\beta$-carotene that comes from Dunaliella is the third most important microalgae industry since 1986 [13]. $\beta$-carotene products derived from Dunaliella are; 1) Dunaliella powder for animal feed production, 2) Dunaliella powder for human food elaboration and 3 ) extracts of pure $\beta$-carotene for medical and pharmaceutical use, with prices oscillating between US $\$ 300$ to US $\$ 3000$ per $\mathrm{kg}$, respectively [13]. Synthetic $\beta$-carotene is easier to obtain and cheaper than $\beta$-carotene from Dunaliella, reason why synthetic molecule dominates almost $95 \%$ of the market.

All-trans-retinoic-acid (ATRA) $\beta$-carotene derived molecule from synthetic and natural sources are $100 \%$ equals in structure and function [14]. ATRA is been considered the most potent biologically active metabolite derived from vitamin A, because prevent and rescue cancer anomalies induced by VAD in adult animals $[15,16]$. Subsequent studies anticipated a strong rationale for use of retinoids in treatment and prevention of cancer [17]. $\beta$-carotene from $D$. salina contains $47 \%$ of $9 \mathrm{C} \beta \mathrm{C}$ and $53 \%$ AT $\beta C$ (Figure 1) [18]. Antiperoxidative9-cis-retinoicacid (9CRA) activity is greater compared to that shown by ATRA, preventing further malignant cells development and cardiovascular diseases [19,20]. Cytochrome P450RAI (CYP26) metabolizes ATRA but not 9CRA isomer increasing its half-life [21,22]. ATRA and 9CRA ligands interact with nuclear retinoic acid receptors (RARs) and retinoic $\mathrm{X}$ receptors (RXRs); ATRA binds to RARs while 9CRA can bind to both RARs and RXRs $[23,24]$. DNA promoter retinoic acid respond elements (RAREs) combinations tightly regulate gene expression, through interaction with homo and heterodimers constituted by RARs and RXRx previously bound to ATRA and 9CRA [25].

In this work $D$. Salina strain isolated from Baja California peninsula of México was identified both morphologically and molecularly via $18 \mathrm{~S}$ $r D N A$ conserved and specific primers $[26,27]$. Natural $\beta$-carotene from optimally grown cells was solvent extracted and quantified. $\beta$-carotene was assessed for its anticancer property in MDA-MB-231 human breast cancer cell line, showing $70 \%$ of effective apoptosis with respect to synthetic $\beta$-carotene that only induced $30 \%$ in a MTT analysis.

\section{Experimental Section}

\section{Dunaliella environmental sampling and growth conditions}

Locations in Baja California peninsula of México were selected for water-sample collection [11]. Environmental samples were obtained using $50 \mathrm{ml}$ plastic tubes from red hypersaline waters between May

*Corresponding author: Jorge Olmos, Department of Marine Biotechnology, Centro de Investigación Científica y de Educación Superior de Ensenada (CICESE), Ensenada, B.C., México, E-mail: jolmos@cicese.mx

Received December 03, 2014; Accepted February 12, 2015; Published February 19, 2015

Citation: Olmos J, Gómez R, Rubio VP (2015) Apoptosis Comparison Effects Between Synthetic and Natural B-Carotene from Dunaliella salina on MDA-MB-231 Brest Cancer Cells. J Microb Biochem Technol 7: 051-056. doi:10.4172/19485948.1000181

Copyright: ( 2015 Olmos J, et al. This is an open-access article distributed under the terms of the Creative Commons Attribution License, which permits unrestricted use, distribution, and reproduction in any medium, provided the original author and source are credited 


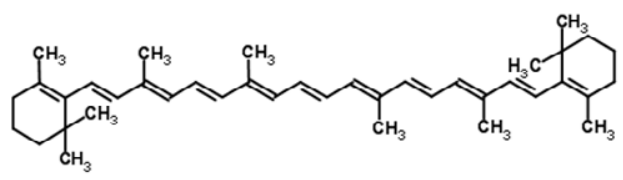

A)

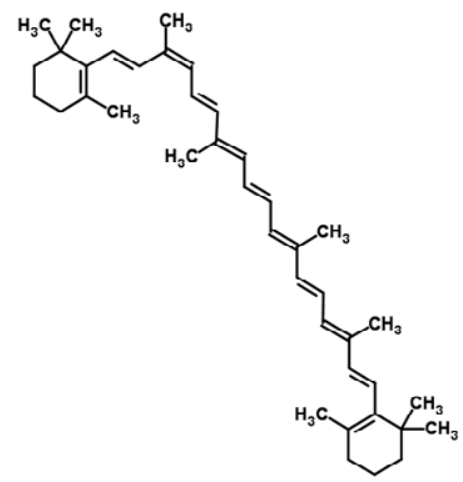

A) CSID:4444129, http://www.chemspider.com/Chemical-Structure.4444129.html B) CSID:8004366, http://www.chemspider.com/Chemical-Structure.8004366.html

Figure 1: A) AT $\beta C$ and B) $9 C \beta C$.

and September 2006. Red flagellated microalgae strains contained in samples were morphologically and molecularly identified as Dunaliella, before purification and growth. Samples containing $D$. salina were serially diluted up to $10^{-4}$ and $0.1 \mathrm{ml}$ spread on $2 \%$ De Walne's agar medium $[3,28]$. Distinct colonies developed on plates were transferred to $\beta$-carotene inducing medium supplemented with $1.0,1.5$ and $2 \mathrm{M}$ of $\mathrm{NaCl}$ and kept at $24 \pm 1^{\circ} \mathrm{C}$ in thermostatically controlled chamber, illuminated with four cool fluorescent lamps to generate an irradiance of $200 \mu \mathrm{E} \mathrm{m}-2 \mathrm{~s}-1$, under $12 \mathrm{~h} / 12 \mathrm{~h}$ light/dark photo period.

\section{DNA Purification and PCR Amplification}

Isolation of chromosomal DNA from Dunaliella strains was carried out and species identification of isolates was developed using MA1 [5'-CGGGATCCGTAGTCATATGCTTGTCTC-3'] and MA2 [5-GGAATTCCTTCTGCAGGTTCACC-3'] conserved and DSs (D. salina) [5'-GCAGGAGAGCTAATAGGA-3'] specific oligonucleotide reported by Olmos and coworkers $[5,11]$. MA1 and MA2 conserved oligonucleotides amplify $18 S \quad r D N A$ complete sequence. DSs oligonucleotide is specific for $\beta$-carotene " $D$. salina var Teod" hyper producer strain $[11,12]$. PCR reactions were carried out in a total volume of $100 \mu \mathrm{l}$ containing $50 \mathrm{ng}$ of chromosomal DNA in TE (TrisEDTA) buffer, pH 8 and 200 ng MA1 and MA2 conserved primers. The amplification was carried out using 25 cycles with a $\mathrm{Tm}$ of $52^{\circ} \mathrm{C}$ to all reactions. One cycle consisted of 1 minute at $95^{\circ} \mathrm{C}, 1$ minute at $52^{\circ} \mathrm{C}$ and 2 minute at $72^{\circ} \mathrm{C}$. PCR with specific primer was combined with MA2 conserved primer (DSs-MA2) and reactions were carried out under same conditions.

\section{$\beta$-Carotene HPLC identification and quantification}

One $\mathrm{ml}$ sample was centrifuged at $2000 \mathrm{rpm}$ for $5 \mathrm{~min}$, supernatant was discarded and pellets were homogenized and disrupted in one $\mathrm{ml}$ of $100 \%$ cold methanol. Samples were incubated on ice for one hour in the dark, centrifuged at $10000 \mathrm{rpm} 5 \mathrm{~min}$, filtered and kept at $-20^{\circ} \mathrm{C} .20$ $\mu \mathrm{l}$ methanol $\beta$-carotene extracted sample was injected into a Hewlett Packard 1100 model HPLC apparatus, using a reverse phase VYDAC $201 \mathrm{TP} 52 \mathrm{C}-18$ column of $4 \mathrm{~mm}$ internal diameter and $150 \mathrm{~mm}$ length, with $5 \mu \mathrm{m}$ particle size. The detector was set at $340 \mathrm{~nm}$ and $450 \mathrm{~nm}$ for identification of $9 \mathrm{C} \beta \mathrm{C}$ and ATRA respectively. Elution was performed with an isocratic mixture of acetonitrile:methanol:tetrahidrofuran:w ater $(70: 15: 10: 5)$ at $0.5 \mathrm{ml} / \mathrm{min}$. Synthetic AT $\beta C$ was obtained from Sigma and used as standard.

\section{Purification of $\beta$-Carotene from $D$. salina}

Thirty days old $D$. salina grown under laboratory condition was centrifuged at $2000 \mathrm{rpm}$ for $5 \mathrm{~min}$ and pellet was collected. Five gram pellets were taken, washed with distilled water and centrifuged again to remove salt. Collected pellets were dissolved with $10 \mathrm{ml}$ of methanol and macerated with mortar and pestle in an ice bath until the pellet became colorless, sample was centrifuged again, pellet was discharged and methanol was evaporated at room temperature. $\beta$-carotene resultant amorphous dry powder was dissolved in olive oil and concentrations of $10 \mu \mathrm{g} / \mathrm{ml}$ were used for following anticancer studies.

\section{Effect of Natural $\beta$-Carotene from D. salina on MDA-MB-231}

Human keratinocytes cells (HaCat) and human Brest cancer cells (MDA-MB-231), were cultured in RPMI-1640 medium supplemented with $10 \%$ inactivated fetal bovine serum (v/v) (GIBCO ), and $1 \%$ antiant commercial antibiotic (invitrogen) in a humidified incubator with $5 \% \mathrm{CO}_{2}$ at $37^{\circ} \mathrm{C}$. The MTT method described by Mosmann was used to quantitatively detect living cells [29]. In brief, $5 \times 10^{3}$ cells/well were charged onto 96 well plates. After $24 \mathrm{~h}$, supplemented medium was discarded, non-supplemented medium was added and cells were incubated $24 \mathrm{~h}$ more. $10 \mu \mathrm{g} / \mathrm{ml}$ solution of synthetic and purified $\beta$-carotene from $D$. salina, were added to HaCat and MDA-MB-231 cells that were incubated $2 \mathrm{~h}$ at the same conditions. Medium was discarded and $100 \mu \mathrm{l}$ of fresh medium was added with $10 \mu \mathrm{L}$ of MTT $(5 \mathrm{mg} / \mathrm{ml})$. After $2 \mathrm{~h}$ of incubation medium was eliminated and $100 \mu \mathrm{l}$ of cold isopropanol was added to dissolve crystals formed. Absorbance was quantified with a microplate reader at $570 \mathrm{~nm}$. Growth inhibition percentage was calculated using DMSO cells treated as positive control and as negative control RPMI medium was used.

\section{DNA fragmentation assay in MDA-MB-231 cells}

Cleavage of DNA was analyzed as described previously [30]. MDAMB-231 cells were grown and treated with a $10 \mu \mathrm{g} / \mathrm{ml} \beta$-carotene solution. Cells were washed twice with ice-cold PBS and resuspended in lysis buffer containing 10 mMTris- $\mathrm{HCl}$ (pH 8.0), $20 \mathrm{mM}$ EDTA, $0.5 \%$ Triton X-100 and incubated for 30 minutes on ice. After centrifugation at $10000 \mathrm{rpm}$ for $10 \mathrm{~min}$ at $4^{\circ} \mathrm{C}$ DNA was extracted with phenol chloroform, precipitated at $-20^{\circ} \mathrm{C}$ overnight with 0.1 volume 3 $\mathrm{M}$ sodium acetate and 2.5-volume ethanol. DNA was pellet at 10000 $\mathrm{rpm}$ for $5 \mathrm{~min}$ and $4^{\circ} \mathrm{C}$, rinsed with $70 \%$ ethanol, resuspended in TE buffer ( $\mathrm{pH} \mathrm{8.0)} \mathrm{contained} 30 \mu \mathrm{g} / \mathrm{ml}$ of RNase and incubated for $6 \mathrm{~h}$ at $37^{\circ} \mathrm{C}$. DNA was run on $2 \%$ agarose gel with ethidium bromide staining and visualized under UV and documented [3].

\section{Results and Discussion}

First description of a unicellular biflagellate red colored alga living in concentrated brines of Montpellier on Mediterranean coast of France was reported in 1838 by Dunal, who described occurrence of 
the organism we know today as Dunaliella salina [31]. Descriptions of Dunaliella (Chlorophyta, Chlorophyceae, Chlamydomonadales, Dunaliellaceae) as a new genus, was presented in year 1905 by Teodoresco from Bucharest using Romanian salt lake samples and by Clara Hamburger from Heidelberg using samples from Cagliari, Sardinia [32,33]. Dunaliella do not have a cell wall only is enclosed by a thin elastic plasma membrane, in this sense species of the genus present a vast morphological variability with respect to environmental conditions were algae growth [34-36]. Dunaliella can be ellipsoid, ovoid to almost spherical, pyriform or fusiform (Figure 2).

Motile cells are biflagellate, with flagella inserted at anterior end of the cell with length varying between species. There is a single large posterior chloroplast occupying most of the cell volume. It is either cup-, dish or bell-shaped and contains a pyrenoid in the thickened basal part in all species except some of the freshwater species [37].

Taxonomic studies among Dunaliella have identified several new species since Teodorescos identification in 1905 [36]. However, high plasticity in green stage and almost indistinguishable differences in red phase make identification and differentiation of species very difficult and time consuming [26]. Dunaliella genus includes a reduced number of species that when exposed to elevated luminous intensities, high saline concentrations, oxygen and nitrogen limitation accumulates great amounts of $\beta$-carotene $[9,10]$. D. salina and D. bardawil are most important species for $\beta$-carotene production; several investigations have demonstrated that both produce more than $10 \%$ of its dry mass [27]. In this sense, Dunaliella isolates were morphological and molecularly identified. Figure 2, shown Dunaliella strain isolated from locations reported by Olmos and coworkers [11], picture presents a microalga growing on a brine lagoon containing high levels of $\beta$-carotene and two flagella, characteristics from a Dunaliella hyperproducer strain. Thus, Intron-Sizing-Method was applied to make an easy, fast and precise identification of the isolates $[11,12]$. In natural samples " $D$. salina var Teod" was identified due its $18 S$ rDNA fingerprinting profile presented a 2100 bp PCR product using MA1-MA2 conserved oligonucleotides and a $700 \mathrm{bp}$ product by using $D$. salina specific and conserved oligonucleotides (DSs-MA2) (Figure 3).

Once isolated strain was identified, it was grown using an inducer medium formulated with addition of three $\mathrm{NaCl}$ concentrations (Table $1)$, to evaluate its influence in growth and $\beta$-carotene production (Figure 4). D. salina isolate reached stationary phase 15 days after initiation of growth culture, approximately $1 \times 10^{6}$ cells were obtained in all $\mathrm{NaCl}$ conditions and $\beta$-carotene production analyzed thirty days after initiation, was slightly greater in $1.5 \mathrm{M}$ of $\mathrm{NaCl}$ (data not shown).

$9 \mathrm{C} \beta \mathrm{C}$ and $\mathrm{AT} \beta \mathrm{C}$ production in green (15 days) and red (30 days)

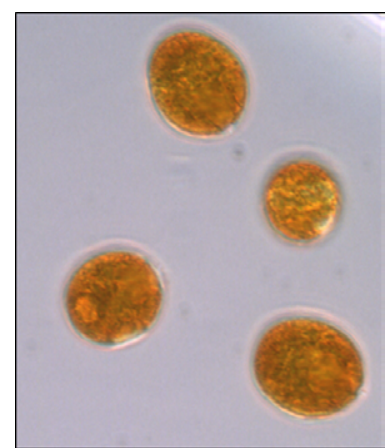

Figure 2: Dunaliella salina isolated strain.

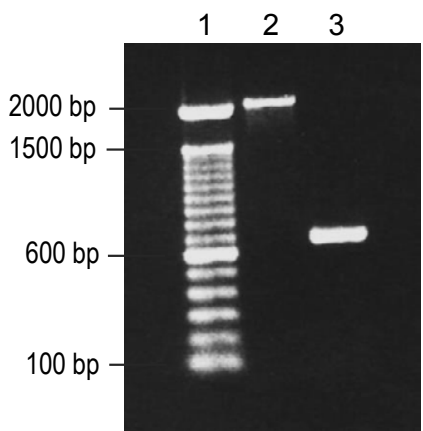

Figure 3: $D$. salina specific identification. Lane 1, Molecular Weight Marker. Lane 2, PCR product using MA1-MA2 conserved primers. Lane 3, PCR product using DSs-MA2 specific-conserved primers.

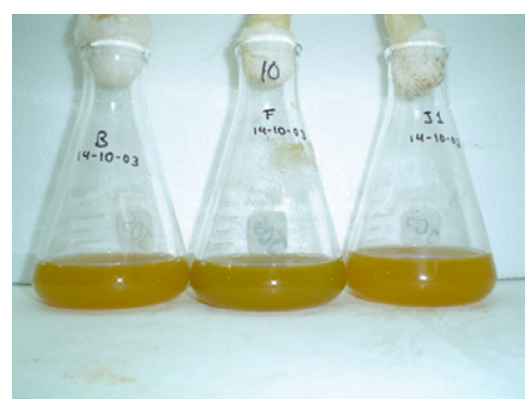

Figure 4: $D$. salina growth under $1,1.5$ and $2 \mathrm{M}$ of $\mathrm{NaCl}$, respectively.

\begin{tabular}{|c|c|}
\hline Component & Concentration \\
\hline $\mathrm{CaCl}_{2}$ & $0.10 \mu \mathrm{M}$ \\
\hline $\mathrm{H}_{3} \mathrm{BO}_{3}$ & $61.7 \mu \mathrm{M}$ \\
\hline $\mathrm{MgSO}_{4}$ & $1.67 \mathrm{mM}$ \\
\hline $\mathrm{TRISMA}$ & $0.48 \mathrm{mM}$ \\
\hline $\mathrm{NaNO}_{3}$ & $1.17 \mathrm{mM}$ \\
\hline $\mathrm{NaH}_{2} \mathrm{PO}_{4}$ & $53.3 \mu \mathrm{M}$ \\
\hline $\mathrm{FeCl}_{3}$ & $13.3 \mu \mathrm{M}$ \\
\hline $\mathrm{EDTA}$ & $13.3 \mu \mathrm{M}$ \\
\hline $\mathrm{ZnSO}_{4}$ & $100 \mathrm{nM}$ \\
\hline $\mathrm{Na}_{2} \mathrm{MoO}_{4}$ & $33 \mathrm{nM}$ \\
\hline $\mathrm{MnCl}_{2}$ & $1.21 \mu \mathrm{M}$ \\
\hline $\mathrm{CoCl}_{2}$ & $53 \mathrm{nM}$ \\
\hline $\mathrm{CuSO}_{4}$ & $46.67 \mathrm{nM}$ \\
\hline Thiamine & $3.5221 \mu \mathrm{M}$ \\
\hline Biotin & $0.024 \mu \mathrm{M}$ \\
\hline Cyanocobalamin & $4.38 \mu \mathrm{M}$ \\
\hline NaCl & $1.0-1.5-2.0 \mathrm{M}$ \\
\hline
\end{tabular}

Table 1: Culture medium with $1,1.5$ and $2 \mathrm{M}$ of $\mathrm{NaCl}$.

phases were evaluated with an HPLC methodology developed. In this sense, $D$. salina isolated strain produces 9 C $\beta$ C:AT $\beta C$ ratio of $70: 30$ under conditions established (Figure 5a). However, results obtained by Sheu and coworkers shown a D. salina strain producing $\beta$-carotene 9C $\beta$ C:AT $\beta C$ ratio of 47:53 [18]. Additionally, it is important to point out that $9 \mathrm{C} \beta \mathrm{C}$ is preferentially produced in red phase, due in green phase $9 \mathrm{C} \beta \mathrm{C}$ :AT $\beta \mathrm{C}$ ratio was inversely proportional (Figure $5 \mathrm{~b}$ ). Results differences obtained between Sheu and this work maybe was due by medium, culture conditions and/or timing of evaluation. Other factors involved in 9C $\beta \mathrm{C}: \mathrm{AT} \beta \mathrm{C}$ ratio differences could be HPLC methodology and/or Dunaliella strain used. 


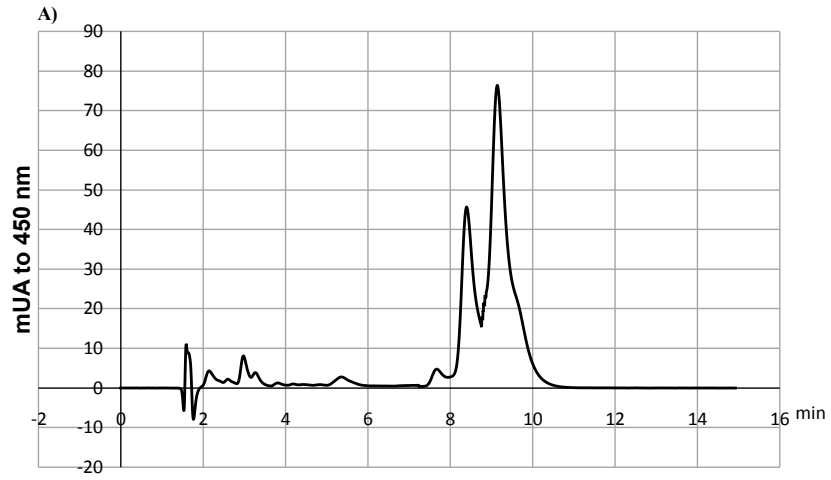

B)

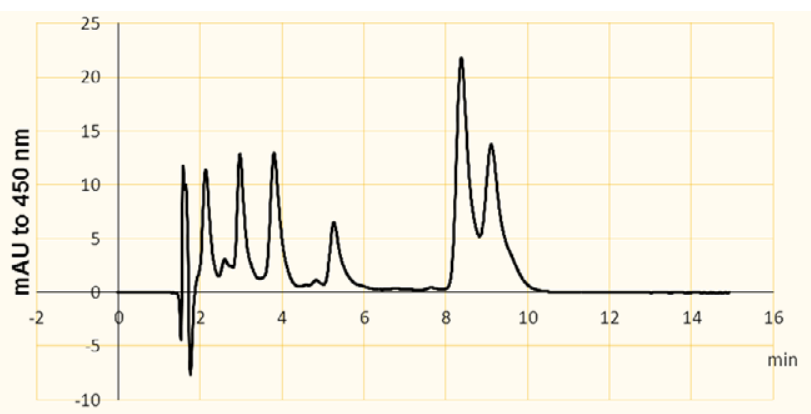

Figure 5: A) $\beta$-carotene red phase extraction and B) $\beta$-carotene green phase extraction.

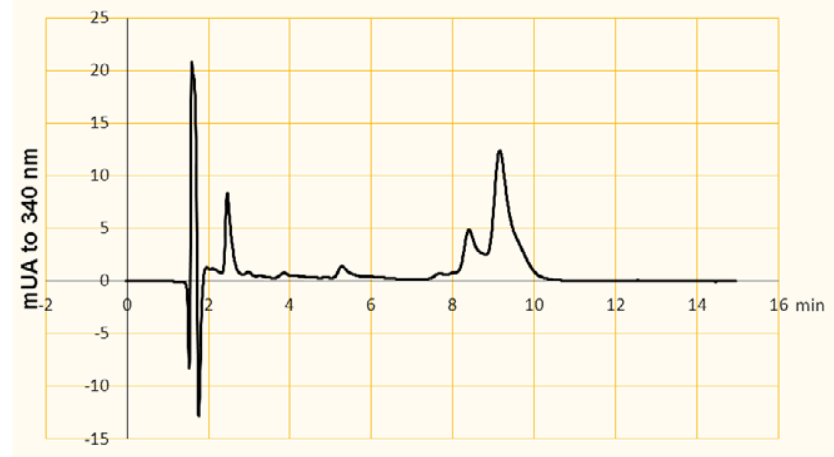

Figure 6: AT $\beta C$ small peak ( $8.5 \mathrm{~min})$ and $9 \mathrm{C} \beta C$ higher peak $(9.5 \mathrm{~min})$.

Moreover, $\beta$-carotene production level reached by our isolate was around $20 \mathrm{mg} / \mathrm{l}$ meaning that formulated medium succeed in its overproduction, as well as in $9 \mathrm{C} \beta \mathrm{C}$ induction. Furthermore, $\beta$-carotene isomers identification was made by using $340 \lambda$, due $9 \mathrm{C} \beta \mathrm{C}$ presents a better absorption than $\mathrm{AT} \beta \mathrm{C}$ at this wavelength [38]. The obtained results corroborate findings made by Briton and coworkers, where D. salina $9 \mathrm{C} \beta \mathrm{C}$ peak showed higher levels than AT $\beta \mathrm{C}$ (Figure 6). Additionally, AT $\beta C$ from $D$. salina presented same retention time as synthetic molecule obtained from Sigma-Aldrich (data not shown). Supporting these findings Grune and coworkers mention that both molecules presented the same structure-function and by consequence the same retention time [14]. Differences between 9C $\beta C: A T \beta C$ ratio from synthetic and natural samples, was not possible to calculate due synthetic just contains AT $\beta$ C molecule.

Metaanalysis of controlled trials using synthetic $\beta$-carotene in Finland (AT $\beta \mathbf{C})$ and synthetic $\beta$-carotene and retinol in USA
(CARET), showed that high levels (20-30 mg/day) of supplemental $\beta$-carotene instead to prevent and control lung cancer, increases risk and percentage of positive cases [6]. In this sense, Palozza and coworkers found that under low oxygen pressure $\left(15 \mathrm{mmHg}_{\mathrm{pO}}\right) \beta$-carotene behaved as antioxidant, inhibiting cigarette smoke condensate (tar) to induced lipid peroxidation [8]. Nevertheless, $\beta$-carotene progressively acted as a prooxidant in a dose-dependent manner under 100 $760 \mathrm{mmHg} \mathrm{pO}_{2}$ range [8]. $\beta$-carotene auto-oxidation, measured as formation of 5,6-epoxy- $\beta, \beta$-carotene, was faster at high than at low $\mathrm{pO}_{2}$ and carotenoid was more rapidly consumed in tar presence [39]. In contrast to AT $\beta C$ and CARET studies, the Physicians' Health Study was conducted among mainly nonsmokers; $50 \mathrm{mg}$ of $\beta$-carotene was given every other day and no effect was found on lung cancer risk in either smokers or nonsmokers [40]. $\beta$-carotene serum concentration $(210-300 \mu \mathrm{g} / \mathrm{dL})$ in trials where lung cancer incidence increased was markedly higher than in Physicians' Health Study $(120 \mu \mathrm{g} / \mathrm{dL})$, where no increase in lung cancer risk was seen from $\beta$-carotene supplementation [40]. Additionally, normal range of serum $\beta$-carotene derived from dietary intake is around $5-50 \mu \mathrm{g} / \mathrm{dL}$ [41]. In this sense, $10 \mu \mathrm{g} / \mathrm{ml}$ of synthetic and natural $\beta$-carotene were supplemented on experiments developed in this work, using MDA-MB-231 Brest cancer and HaCat cell lines (Figure $7 \mathrm{a}$ and $7 \mathrm{~b}$ ). Due $\beta$-carotene low levels used in these assays and low culture plates $\mathrm{pO}_{2}$, pro-oxidant activity was discarded in these experiments. Obtained results in MDA-MB-231 Brest cancer cells shown that $\beta$-carotene from Dunaliella induced $70 \%$ cells death with respect to synthetic molecule that only presented $30 \%$ in MTT assays (Figure $7 \mathrm{a}$ ). These results are in agreement with cell and animal model trials published, where induction of apoptosis at different levels was carried out by $D$. salina extracts $[3-5,18]$. Nevertheless, no one of the mentioned authors had worked with MDA-MB-231 Brest cancer cells neither HaCat, only Prakash and coworkers made some
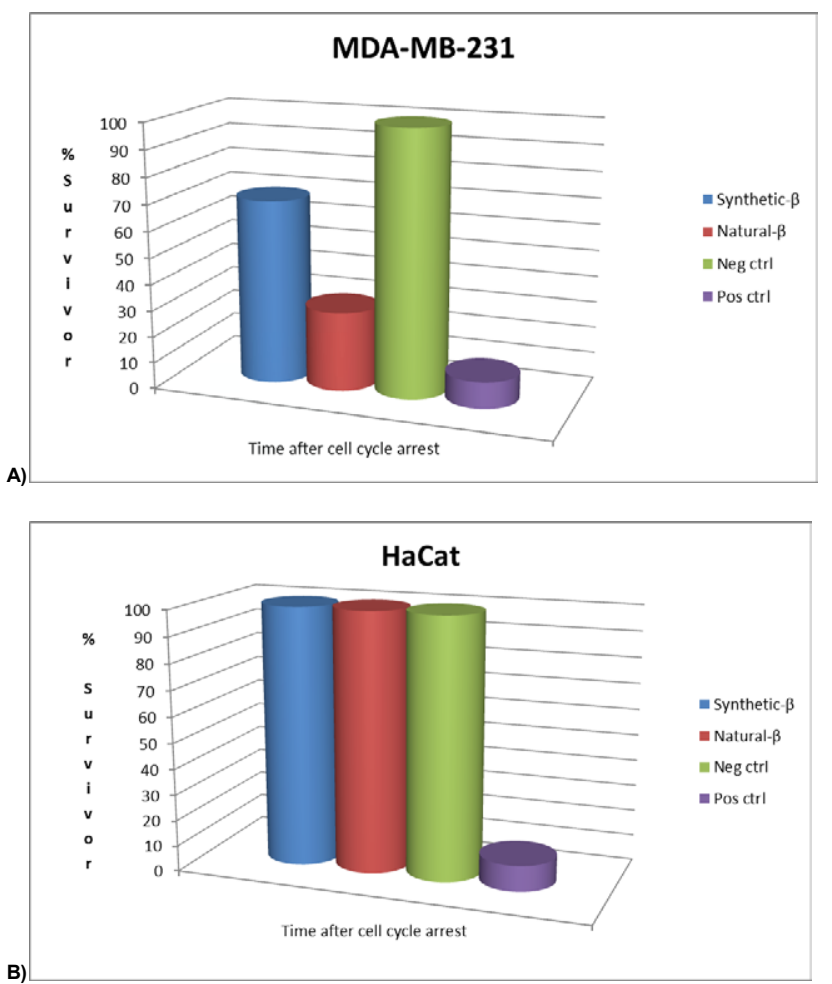

Figure 7: Synthetic and Natural $\beta$-carotene used to treat; A) MDA-MB-231 and B) HaCat cells. 
$\beta$-carotene inhibition test in MDA-MB-231 cells, but non-results were reported [42]. Breast cancer is the most frequently diagnosed cancer globally and main cause of death among women $[1,2]$. For these reasons, Brest cancer is one of the most important targets to natural and synthetic molecules development. Major carotenoids in D. salina include AT $\beta C$ and 9C $\beta C$; specifically 9-cis isomer had demonstrated a great antiperoxidative effect due to higher reactivity of cis bond compared to trans [5]. In addition, 70\% MDA-MB-231 apoptotic induced cells using natural $\beta$-carotene was in accordance to higher $9 \mathrm{C} \beta C$ levels produced by $D$. salina isolate (Figure $7 \mathrm{a}$ and $5 \mathrm{a}$ ). On the other hand, MDA-MB-231 synthetic $\beta$-carotene treated cells reached $30 \%$ mortality only (Figure $7 \mathrm{a}$ ). Thus, obtained results suggest that $9 \mathrm{C} \beta \mathrm{C}$ is the most influential isomer in apoptosis induction in MDA-MB-231 Brest cancer cells. Moreover, non-deleterious effects in $\mathrm{HaCat}$ cells were induced by $\beta$-carotene treatment, meaning that used concentration was not harmful to tested cells (Figure 7b). Additionally, it is important to point out that failed human clinical trials in Finland and USA (AT $\beta C$ and CARET), were developed using high levels of synthetic $\beta$-carotene and without inclusion of $9 C \beta C$ [6]. In this sense, clinical trials development using natural $\beta$-carotene with high levels of 9-cis isomer are recommended, due results obtained in this work and other reports published [3-5,18]. For this reason, a culture medium specifically formulated to overproduce $9 \mathrm{C} \beta C$ in $D$. salina, as the one developed in this work is required. Additionally, timing to $D$. salina $\beta$-carotene harvesting is also of extreme importance to obtain the greatest $9 \mathrm{C} \beta \mathrm{C}$ concentration (Figure $5 \mathrm{a}$ and $5 \mathrm{~b}$ ). In addition, $D$. salina species-specific identification is highly recommended to obtain desired results.

With respect to DNA fragmentation assays better degradation results were obtained in MDA-MB-231 Brest cancer cells treated with natural instead of synthetic $\beta$-carotene (data not shown), results expected due better apoptosis induction obtained using natural molecules (Figure $7 \mathrm{a}$ ) and by previously reported works using $D$. salina extracts [3-5,18]. Evasion of apoptosis is considered a hallmark of human cancers; apoptosis cell death modality is executed by caspases, which are up-regulated by factors like retinoids [43-45]. Although, caspases activity is regulated primarily at post-translational level its overexpression sensitizes cells for apoptosis [43-45]. In addition, CYP26 expression is regulated by ATRA and 9CRA throughout RARs and RXRs nuclear receptors. Furthermore, an important function of RARs and RXRs receptors is auto-regulate their own activity by controlling CYP26 transcription that in turn, controls ATRA ligand concentration by its degradation but without affecting 9CRA [22,23,25,46]. In this sense, caspase and CYP genes expression is modulated by ATRA and 9CRA ligands; however, 9-cis activate both RARs and RXRs nuclear receptors, while ATRA only activate RARs regulators [23]. Therefore, data mentioned above could explain why 9C 3 C:AT $\beta C$ (70:30) ratio obtained from $D$. salina, induces apoptosis more efficiently than AT $\beta C$ from synthetic origin. Additionally, presence of both isomers seems to be imperative for a correct RXR:RAR heterodimer genes regulation and expression [25].

\section{Conclusion}

Retinoid regulates a wide variety of essential biological processes, such as vertebrate embryonic morphogenesis and organogenesis, cell growth arrest, differentiation and apoptosis, as well as, homeostasis and their disorders [15,47-49]. VAD is been related with cancer, although controlled trials using synthetic $\beta$-carotene increased the disease in smokers. 9CRA and ATRA are the most potent biologically active metabolites derived from natural $\beta$-carotene (9C $\beta \mathrm{C}: \mathrm{AT} \beta \mathrm{C})$; a pro-vitamin A molecule isolated principally from Dunaliella species. However, synthetic $\beta$-carotene only generates ATRA and non-9CRA is detected in human bodies. Commercial price differences between both isomers are of great concern, reason why synthetic $\beta$-carotene (AT $\beta A)$ is been used preferentially for a long period. 9CRA and ATRA regulates gene expression throughout interactions with nuclear retinoic acid receptors (RARs) and retinoic X receptors (RXRs), being RXRs the most important and represented in human bodies. DNA promoter retinoic acid respond elements (RAREs) combinations tightly regulate gene expression through homo and heterodimerization between RXRx and RARs, after interaction with 9CRA and ATRA. In this sense, presence of both retinoids is indispensable to an accurate gene expression and apoptosis induction as was demonstrated in this work. Pending tasks are related to know about precise ratio needed between 9CRA:ATRA and the concentration that must be apply, to prevent and/or to cure cancer in humans. Meta-analysis already demonstrated that application of high levels of synthetic ATRA one of the two components of the ratio, is not adequate to prevent neither to cure cancer. Utilization of natural sources of $\beta$-carotene like $D$. salina is more expensive at the beginning, but at the end could be cheaper preventing this kind of diseases.

\section{References}

1. Jemal A, Bray F, Center MM, Ferlay J, Ward E, et al. (2011) Global cancer statistics. CA Cancer J Clin 61: 69-90.

2. Mendoza G, Portillo A, Olmos-Soto J (2013) Accurate breast cancer diagnosis through real-time PCR her-2 gene quantification using immunohistochemicallyidentified biopsies. Oncol Lett 5: 295-298.

3. Jayappriyana KR, Rajkumarb R, Venkatakrishnanc V, Nagarajd S, Rengasamyd $R$ (2013) In vitro anticancer activity of natural ß-carotene from Dunaliella salina EU5891199 in PC-3 cells. Biomed Prevent Nutr 3: 99-105.

4. Raja R, Hemaiswarya S, Balasubramanyam D, Rengasamy R (2007) Protective effect of Dunaliella salina (Volvocales, Chlorophyta) against experimentally induced fibrosarcoma on wistar rats. Microbiol Res 162: 177-184.

5. Tsai CF, Lu FJ, Hsu YW (2012) Protective effects of Dunaliella salina - a carotenoids-rich alga - against ultraviolet B-induced corneal oxidative damage in mice. Mol Vis 18: 1540-1547.

6. Druesne-Pecollo N, Latino-Martel P, Norat T, Barrandon E, Bertrais S, et al. (2010) Beta-carotene supplementation and cancer risk: a systematic review and metaanalysis of randomized controlled trials. Int J Cancer 127: 172-184.

7. Misotti AM, Gnagnarella P (2013) Vitamin supplement consumption and breast cancer risk: a review. Ecancermedicalscience 7: 365 .

8. Palozza P, Serini S, Trombino S, Lauriola L, Ranelletti FO, et al. (2006) Dual role of beta-carotene in combination with cigarette smoke aqueous extract on the formation of mutagenic lipid peroxidation products in lung membranes: dependence on pO2. Carcinogenesis 27: 2383-2391.

9. Ben-Amotz A Katz A Avron M (1982) Accumulation of B-carotene in halotolerant algae: purification and characterization of $B$-carotene-rich globules from Dunaliella bardawil (Chlorophyceae). J Phycol 18: 529-537.

10. Borowitzka LJ. The microflora: Adaptations to life in extremely saline lakes. Hydrobiologia 1981, 81, 33-46.

11. Olmos J, Ochoa L, Paniagua-Michel J, Contreras R (2009) DNA fingerprinting differentiation between beta-carotene hyperproducer strains of Dunaliella from around the world. Saline Systems 5: 5 .

12. Olmos SJ, Paniagua-Michel J, Contreras R, Ochoa L (2012) DNA fingerprinting intron-sizing, and sensitive identification of carotenogenic Dunaliella species. In Microbial Carotenoids from Bacteria and Microalgae, 1st ed.; Barredo, J.L.; Ed. Human Press, c/o Springer Science + Bussines Media, LLC, New York USA, , pp 269-281.

13. Spolaore $P$, Joannis-Cassan C, Duran E, Isambert A (2006) Commercial applications of microalgae. J Biosci Bioeng 101: 87-96.

14. Grune T, Lietz G, Palou A, Ross AC, Stah W, et al. (2010) Beta-carotene is an important vitamin A source for humans. J Nutr 140: 2268S-2285S. 
Citation: Olmos J, Gómez R, Rubio VP (2015) Apoptosis Comparison Effects Between Synthetic and Natural B-Carotene from Dunaliella salina on MDA-MB-231 Brest Cancer Cells. J Microb Biochem Technol 7: 051-056. doi:10.4172/1948-5948.1000181

15. Kastner P, Mark M, Chambon P (1995) Nonsteroid nuclear receptors: what are genetic studies telling us about their role in real life? Cell 83: 859-869.

16. Wolbach SB, Howe PR (1925) Tissue changes following deprivation of fatsoluble a vitamin. J Exp Med 42: 753-777.

17. Hong WK, Sporn MB (1997) Recent advances in chemoprevention of cancer. Science 278: 1073-1077

18. Sheu MJ, Huang GJ, Wu CH, Chen JS, Chang HY, et al. (2008) Ethanol extract of Dunaliella salina induces cell cycle arrest and apoptosis in A549 human nonsmall cell lung cancer cells. In Vivo 22: 369-378.

19. Ben-Amotz A, Levy $Y$ (1996) Bioavailability of a natural isomer mixture compared with synthetic all-trans beta-carotene in human serum. Am J Clin Nutr 63: 729-734.

20. Levin G, Yeshurun M, Mokady S (1997) In vivo antiperoxidative effect of 9-cis beta-carotene compared with that of the all-trans isomer. Nutr Cancer 27: 293-297.

21. Niederreither K, Abu-Abed S, Schuhbaur B, Petkovich M, Chambon P, et al. (2002) Genetic evidence that oxidative derivatives of retinoic acid are not involved in retinoid signaling during mouse development. Nat Genet 31: 84-88.

22. Loudig O, Babichuk C, White J, Abu-Abed S, Mueller C, et al. (2000) Cytochrome P450RAI(CYP26) promoter: a distinct composite retinoic acid response element underlies the complex regulation of retinoic acid metabolism. Mol Endocrinol 14: 1483-1497.

23. Germain P, Chambon P, Eichele G, Evans R, Lazar M, et al. (2006) International Union of Pharmacology LX. Retinoic acid receptors. Pharmacol Rev 58: 712725.

24. Lou X, Toresson G, Benod C, Suh JH, Philips KJ, et al. (2014) Structure of the retinoid $X$ receptor $\hat{I} \pm$-liver $X$ receptor $\hat{i}^{2}\left(R X R \hat{I} \pm-L X R \hat{l}^{2}\right)$ heterodimer on DNA. Nat Struct Mol Biol 21: 277-281.

25. Evans RM, Mangelsdorf DJ (2014) Nuclear Receptors, RXR, and the Big Bang Cell 157: 255-266.

26. Olmos J, Paniagua J, Contreras R (2000) Molecular identification of Dunaliella sp. utilizing the 18S rDNA gene. Lett Appl Microbiol 30: 80-84

27. Olmos SJ, Paniagua-Michel J, Contreras R, Trujillo L (2002) Molecular identification of $ß$-carotene hyper-producing strain of Dunaliella from saline environment using specie-specific oligonucleotides. Biotechnol Lett 24: 365-369.

28. Droop MR (1967) A procedure for routine purification of algal culture with antibiotics. Br Phycol Bull 3: 295-297.

29. Mosmann T (1983) Rapid colorimetric assay for cellular growth and survival: application to proliferation and cytotoxicity assays. J Immunol Methods 65: 5563.

30. Kim IJ, Ko KC, Kim CS, Chung W (2001) Isolation and expression pattern of a cDNA encoding phytoene synthase in Citrus. J Plant Physiol 158: 795-800.

31. Oren A (2005) A hundred years of Dunaliella research: 1905-2005. Saline Systems 1: 2.

32. Teodoresco EC (1905) Organisation et développement du Dunaliella, nouveau genre de Volvocacée-Polyblepharidée. Beih. Z. Bot Centralbl Bd. XVIII, 215-232.

33. Hamburger C (1905) Zur Kenntnis der Dunaliella salina und einer Amöbe aus Salinenwasser von Cagliari. Arch F Protistenkd 6: 111-131.

34. Butcher RW (1959) An introductory account of the smaller algae of british coastal waters. Part I: Introduction and Chlorophyceae London: Ministry for Agriculture, Fisheries and Food, Fishery Investigations, Series IV. Her Majesty's Stationery Office.

35. Lerche W (1937) Untersuchungen über Entwicklung und Fortpflanzung in der Gattung Dunaliella. Arch F Protistenkd 88: 236-268.
36. Massyuk NP (1973) Morphology, Taxonomy, Ecology and Geographic Distribution of the Genus Dunaliella Teod and Prospects for its Potential Utilization. Kieve, Naukova Dumka,

37. Borowitzka MA Siva CJ (2007) The taxonomy of the genus Dunaliella (Chlorophyta, Dunaliellales) with emphasis on the marine and halophilic species. J Appl Phycol 19: 567-590.

38. Britton G, Pfander H, Lian-Jensen S (1995) Carotenoids today and Challenges for the Future. In Carotenoids, Vol. 1A: Isolation and Analisis. Britton, G LiaaenJensen, S. Pfander, H. eds. Birkhäuser Verlag Basel, Switzerland, pp 328.

39. Palozza P, Serini S, Di Nicuolo F, Boninsegna A, Torsello A, et al (2004) B-Carotene exacerbates DNA oxidative damage and modifies p53-related pathways of cell proliferation and apoptosis in cultured cells exposed to tobacco smoke condensate. Carcinogenesis 25: 1315-1325.

40. Russell RM (2004) The enigma of beta-carotene in carcinogenesis: what can be learned from animal studies. J Nutr 134: 262S-268S.

41. Dietary Reference Intakes for Vitamin C, Vitamin E, Selenium and Carotenoids Food and Nutrition Board, Institute of Medicine, National Academy Press, Washington, D.C. 2000.

42. Prakash P, Russell RM, Krinsky NI (2001) In vitro inhibition of proliferation of estrogen-dependent and estrogen-independent human breast cancer cells treated with carotenoids or retinoids. J Nutr 131: 1574-1580.

43. Mrass P, Rend M, Mildner M, Gruber F, Lengauer B, et al (2004) Retinoic acid increases the expression of p53 and proapoptotic caspases and sensitizes keratinocytes to apoptosis: A possible explanation for tumor preventive action of retinoids. Cancer Res 64: 6542-6548.

44. Olsson M, Zhivotovsky B (2011) Caspases and cancer. Cell Death Differ 18: 1441-1449.

45. Donato LJ, Noy N (2005) Suppression of mammary carcinoma growth by retinoic acid: proapoptotic genes are targets for retinoic acid receptor and cellular retinoic acid-binding protein II signaling. Cancer Res 65: 8193-8199.

46. Zhang QY, Dunbar D, Kaminsky L (2000) Human cytochrome P-450 metabolism of retinals to retinoic acids. Drug Metab Dispos 28: 292-297.

47. Blomhoff R (1994) Transport and metabolism of vitamin A. Nutr Rev 52: S13-23.

48. Chambon $P$ (2005) The nuclear receptor superfamily: a personal retrospect on the first two decades. Mol Endocrinol 19: 1418-1428.

49. Sporn MB, Roberts AB, Goodman DS (1994) The Retinoids: Biology, Chemistry and Medicine. (2nd edition) Raven Press, New York. 